Article

\title{
Immobilization of Arylmalonate Decarboxylase
}

\author{
Kristína Markošová ${ }^{1}$, Jana Husarčíková ${ }^{1}$, Monika Halásová ${ }^{1}$, Robert Kourist ${ }^{2}$, , \\ Michal Rosenberg ${ }^{1}$, Radek Stloukal ${ }^{3}$, Ludmila Zajoncová ${ }^{4}$ and Martin Rebroš ${ }^{1, *}$ \\ 1 Institute of Biotechnology, Faculty of Chemical and Food Technology, Slovak University of Technology, \\ Radlinského 9, 81237 Bratislava, Slovakia; kristina.markosova@stuba.sk (K.M.); \\ j.husarcikova@gmail.com (J.H.); halasova.monika@gmail.com (M.H.); michal.rosenberg@stuba.sk (M.R.) \\ 2 Institute of Molecular Biotechnology, Graz University of Technology, Petersgasse 14, A8010 Graz, Austria; \\ r.kourist@googlemail.com \\ 3 LentiKat's, a.s., Evropská 846/176a, 16000 Prague 6, Czech Republic; radek.stloukal@seznam.cz \\ 4 Department of Biochemistry, Palacký University Olomouc, Šlechtitel 2778371 Olomouc, Czech Republic; \\ ludmila.zajoncova@upol.cz \\ * Correspondence: martin.rebros@stuba.sk, Tel.: +421-259-325-480
}

Received: 25 September 2018; Accepted: 27 November 2018; Published: 2 December 2018

\begin{abstract}
Arylmalonate decarboxylase (AMD) is a monomeric enzyme of only $26 \mathrm{kDa}$. A recombinant AMDase from Bordetella bronchiseptica was expressed in Escherichia coli and the enzyme was immobilized using different techniques: entrapment in polyvinyl alcohol (PVA) gel (LentiKats ${ }^{\circledR}$ ), covalent binding onto magnetic microparticles (MMP, PERLOZA s.r.o., Lovosice, Czech Republic) and double-immobilization (MMP-LentiKats ${ }^{\circledR}$ ) using the previous two methods. The double-immobilized AMDase was stable in 8 repeated biocatalytic reactions. This combined immobilization technique has the potential to be applied to different small proteins.
\end{abstract}

Keywords: arylmalonate decarboxylase; immobilization; LentiKats; magnetic microparticles

\section{Introduction}

Arylmalonate decarboxylase [EC 4.1.1.76, AMDase] is a biotechnologically important enzyme, recently reviewed by Myiamoto and Kourist [1], which is able to catalyse an enantioselective decarboxylation of $\alpha$-aryl- $\alpha$-methylmalonates forming corresponding $\alpha$-arylalkanoates and carbon dioxide, such as decarboxylation of $\alpha$-phenylmalonic acid forming $\alpha$-phenylacetic acid (Figure 1) [2]. This enzyme has the unique ability to produce optically active $\alpha$-arylpropionates that are part of an important class of nonsteroidal anti-inflammatory drugs (NSAIDs) [3], widely used against pain, fever and inflammation due to their analgesic, antipyretic and anti-inflammatory effects [4]. The AMDase shows high enantioselectivity and has been used for the preparation of optically pure aryl, alkenyl, aliphatic and hydroxycarboxylic acids, such as flurbiprofen or naproxen [5-7]. Arylmalonate decarboxylase from Bordetella bronchiseptica has been modified by protein engineering to increase the racemase activity [8]. The mechanism of asymmetric decarboxylation of AMDase has also been described; it was proposed that the Cys 188 in AMDase can act as a proton donor to form the asymmetric center of the product [9]. 


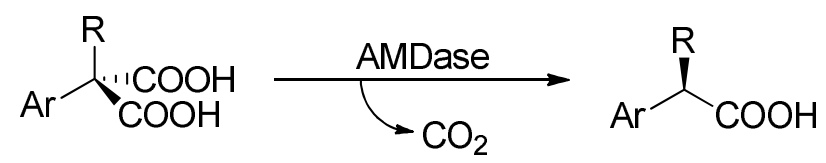

$$
\begin{aligned}
& \mathrm{Ar}=\mathrm{Ph}, \text { 2-naphthyl, 2-thienyl } \\
& \mathrm{R}=\mathrm{H}, \mathrm{CH}_{3}, \mathrm{~F}, \mathrm{NH}_{2}, \mathrm{OH}
\end{aligned}
$$

Figure 1. Reaction catalyzed by AMDase [7].

The application of enzymes is often complicated due to the lack of long-term stability or the difficulty in enzyme recovery and recycling [10]. To improve enzyme activity, and increase thermodynamic and kinetic stability, many immobilization techniques are available and have been described in the literature [11-13]. One of the methods used for the entrapment of enzymes is the LentiKats ${ }^{\circledR}$ system of polyvinyl alcohol (PVA) gel-based lens-shaped particles, which has successfully been applied to the immobilization of many enzymes [14]. Another immobilization method is enzyme adsorption on various carriers, as described in $[15,16]$. As a novel approach, immobilization is now also undertaken on the surface of magnetic particles, a method that has so far mostly been tested in the area of bioscience and medicine, especially for drug targeting and bioseparation, including cell sorting [17]. Moreover, the method has been applied in diagnostics, molecular biology, bioinorganic chemistry and catalysis [18]. The immobilization of enzymes via direct binding on magnetic particles has also been described [19]. Various biotechnologically important proteins and enzymes have been immobilized on fine magnetic particles, such as bovine serum albumin, glucose oxidase, streptokinase, chymotrypsin and dispase [20].

So far, there has been only two reports for AMDase immobilization: on polystyrene nanoparticles, without a significant loss of enzyme activity after four repeated conversions [21], and on amino C2 acrylate, with about $40 \%$ loss of the initial activity after the fourth conversion [22].

The novel approach to immobilization presented in this paper combines two immobilization techniques. The crude enzyme extract (CEE) of recombinant arylmalonate decarboxylase was first covalently bonded onto magnetic microparticles (MMP) and subsequently entrapped in PVA gel (LentiKats ${ }^{\circledR}$ ). The characterization of the immobilized enzyme and its repeated use was tested and compared with the free enzyme.

\section{Results and Discussion}

\subsection{AMDase production}

The enzyme was prepared according to a routinely used protocol using IPTG (isopropyl $\beta$-D-1-thiogalactopyranoside) for induction [23]. The presence of the target protein was verified by sodium dodecyl sulfate polyacrylamide gel electrophoresis (SDS-PAGE) (Mini PROTEAN ${ }^{\circledR}$ Tetra Cell, Bio-Rad, Hercules, CA, USA), observing the band of $26 \mathrm{kDa}$. The whole-cell biomass was inactive (data not shown). This was ascribed to the phenol structure of $\alpha$-phenylmalonic acid, which hampers the penetration of the cell membrane. For this reason, AMDase CEE was used with activity of $82.8 \mathrm{U} / \mathrm{mL}$ CEE (66.03 U/mg $\mathrm{meE})$. The enzyme was tested for its stability. At $4{ }^{\circ} \mathrm{C}$, the enzyme had activity $0.18 \mathrm{U} / \mathrm{mL}$ after two weeks and $0.03 \mathrm{U} / \mathrm{mL}$ after three weeks. Storage of the enzyme in the form of CEE (without addition of any cryoprotectants) at $-80{ }^{\circ} \mathrm{C}$ resulted in almost $100 \%$ of original activity after three weeks.

\subsection{Immobilization and Characterization of AMDase in LentiKats ${ }^{\circledR}$}

To improve the enzyme stability and enzyme properties, AMDase CEE was immobilized in polyvinyl alcohol (PVA) gel (LentiKats ${ }^{\circledR}$ ). It was previously reported that immobilized cell lysate is more stable than immobilized purified enzyme [22]. The activity obtained was $24.2 \mathrm{U} / \mathrm{mL}$ (calculated per $\mathrm{mL}$ of immobilized CEE), approx. $1.64 \mathrm{U} / \mathrm{g}_{\mathrm{LK}}$, which means that the enzyme lost about $70.8 \%$ of its activity as a free enzyme. The possible explanation for this major drop might be due to the fact 
that AMDase is a small monomeric enzyme and was not entirely entrapped. Also the interaction between the PVA monomers and the enzyme may decrease the activity of the enzyme. Compared with another small enzyme, hydroxynitrile lyase $(28-30 \mathrm{kDa})$, also immobilized using LentiKats ${ }^{\circledR}$ technology, displayed a 13\% residual activity after entrapment [24].

The $\mathrm{pH}$, temperature profiles and kinetic parameters were compared with the free form of the enzyme. The $\mathrm{pH}$ profile (Figure 2 ) was only slightly affected by immobilization. The immobilized enzyme was equally active in the range of $7.5-8.5$, whereas the free enzyme at $\mathrm{pH} 7.5$ retained only $45 \%$ relative activity. This confirms that PVA gel has a protective effect on the biocatalyst, even though at $\mathrm{pH} 7$ the enzyme was completely inactive in both forms. The shift in $\mathrm{pH}$ activity to the acidic region was observed as well with the native AMDase from A. bronchisepticus KU 1201 [2].

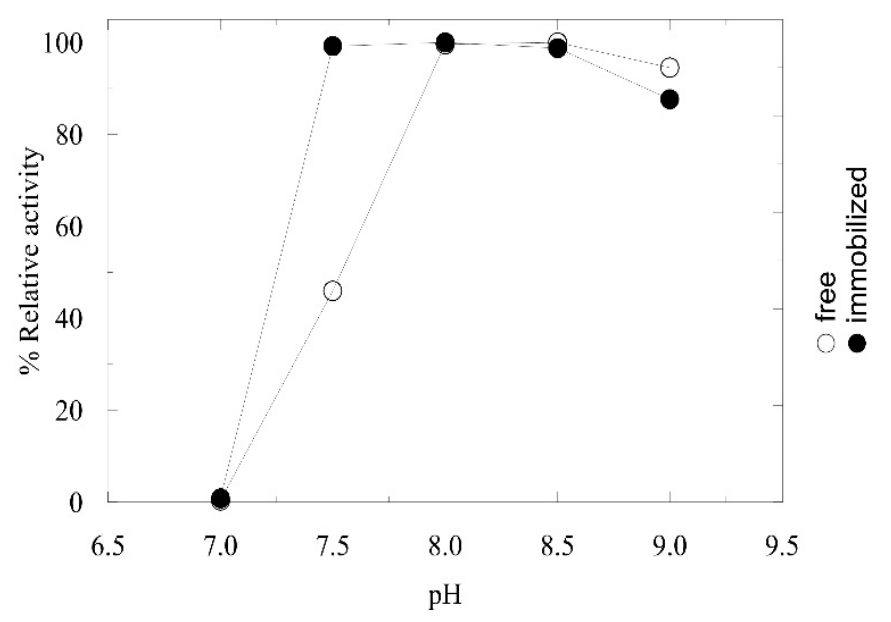

Figure 2. $\mathrm{pH}$ profiles of free and immobilized AMDase crude enzyme extract. Reaction conditions: $5 \mathrm{~mL}$ Tris $\mathrm{HCl}$ (Tris(hydroxymethyl)aminomethane hydrochloride) buffer (100 mM), $\alpha$-phenylmalonic acid $1.8 \mathrm{~g} / \mathrm{L}, 0.5 \mathrm{~g}$ of LentiKats ${ }^{\circledR}$ (immobilized form) or $0.013 \mathrm{mg}$ of enzyme (free form); $37^{\circ} \mathrm{C}$ and $200 \mathrm{rpm}$.

The temperature profiles (Figure 3) also showed some slight differences between the free and immobilized AMDase CEE. The optimum temperature for the immobilized biocatalyst was $37^{\circ} \mathrm{C}$, the same as in [2]; at $25{ }^{\circ} \mathrm{C}$ the activity decreased to $70 \%$ of relative activity for immobilized CEE and to $50 \%$ for the free enzyme. Higher temperatures were not tested due to the low stability of the PVA particles [25].

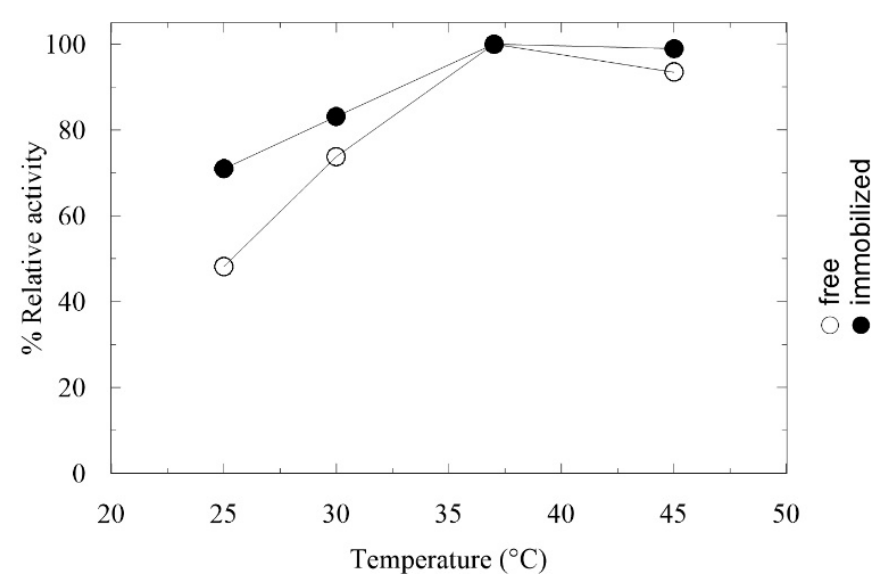

Figure 3. Temperature profiles of free and immobilized AMDase crude enzyme extract. Reaction conditions: $5 \mathrm{~mL}$ TrisHCl buffer $(100 \mathrm{mM}, \mathrm{pH}=8.5), \alpha$-phenylmalonic acid $1.8 \mathrm{~g} / \mathrm{L}, 0.5 \mathrm{~g}$ of LentiKats ${ }^{\circledR}$ (immobilized form) or $0.013 \mathrm{mg}$ of enzyme (free form); $200 \mathrm{rpm}$. 
The kinetic parameters were calculated according to the Michaelis-Menten linearized equation [26] with different concentrations of $\alpha$-phenylmalonic acid as a substrate. The comparison of the Michaelis constant $\left(\mathrm{K}_{\mathrm{m}}\right)$ and maximum initial velocity $\left(\mathrm{V}_{\max }\right)$ values are shown in Table 1 . The value of $K_{m}$ was higher for both free and immobilized enzymes than the values described elsewhere (0.3-13.9 $\mathrm{mM},[2,27-29])$. The possible explanation could be that the reactions were performed with CEE, whereas other enzymes or proteins can interfere with the activity of AMDase or with the substrate. Also the turnover rate is approx. 3.5 times lower than the one described in [29]. The immobilized AMDase had 1.5 times higher $\mathrm{K}_{\mathrm{m}}$ than the free enzyme, which was the case also with other enzymes immobilized in LentiKats ${ }^{\circledR}[30,31]$. It is difficult to say whether the higher $K_{m}$ was due to the limitations caused by immobilization, or because of the enzyme. The turnover rate of CEE LentiKats ${ }^{\circledR}$ is approximately 10 times lower than the one of AMDase immobilised on polystyrene nanoparticles [21].

Table 1. Kinetic parameters of AMDase in free and immobilized form.

\begin{tabular}{cccc}
\hline Kinetic Parameters & CEE Free & CEE LentiKats $^{\circledR}$ & CEE MMP-LentiKats $^{\circledR}$ \\
\hline $\mathrm{K}_{\mathrm{m}}[\mathrm{mM}]$ & 25.2 & 38.6 & 67.2 \\
$\mathrm{~V}_{\max }\left[\mathrm{U} / \mathrm{mg}_{\mathrm{CEE}}\right]$ & 204.5 & 80 & 1.85 \\
$\mathrm{k}_{\mathrm{cat}}\left[\mathrm{s}^{-1}\right]$ & 88.62 & 34.67 & 0.8 \\
$\mathrm{k}_{\text {cat }} / \mathrm{K}_{\mathrm{m}}\left[\mathrm{s}^{-1} \cdot \mathrm{mM}^{-1}\right]$ & 3.52 & 0.9 & 0.01 \\
\hline
\end{tabular}

A comparative biocatalytic reaction was performed with free and immobilized AMDase (Figure 4) with $10 \mathrm{~g} / \mathrm{L}$ of the substrate to see the ability of the biocatalyst to perform a complete substrate conversion. The reactions were performed using $0.82 \mathrm{U}$ of both immobilized and free CEE $(0.5 \mathrm{~g}$ of LentiKats ${ }^{\circledR}$ or $0.013 \mathrm{mg}$ of AMDase CEE). Using the immobilized enzyme, the conversion reached $100 \%$ after $20 \mathrm{~h}$, while with the free enzyme the conversion was not completed even after $120 \mathrm{~h}$. This clearly demonstrates that the enzyme was stabilized by the PVA gel, as also observed in [32].

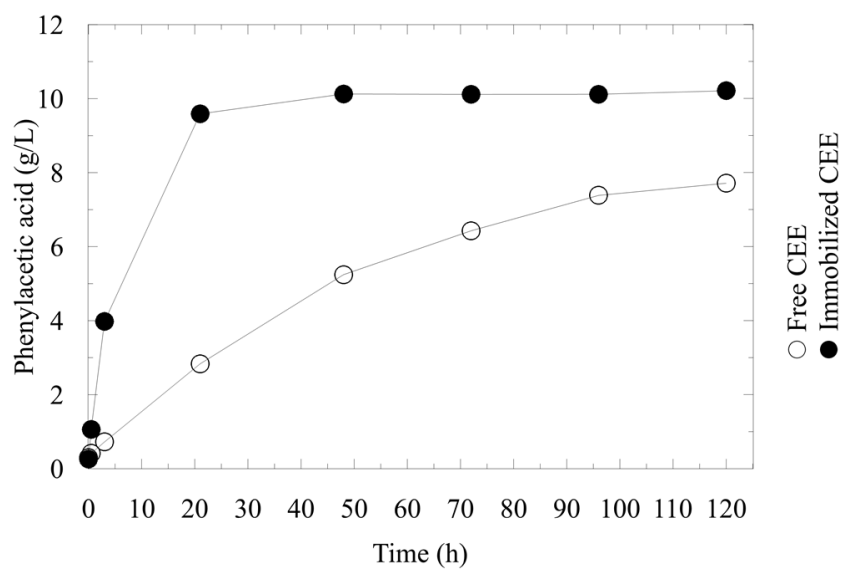

Figure 4. Comparison of biocatalytic reaction by free and immobilized AMDase crude enzyme extract. Reaction conditions: $5 \mathrm{~mL}$ TrisHCl buffer $(100 \mathrm{mM}, \mathrm{pH}=8.5), \alpha$-phenylmalonic acid $10 \mathrm{~g} / \mathrm{L}, 0.5 \mathrm{~g}$ of LentiKats ${ }^{\circledR}$ (immobilized form) or $0.013 \mathrm{mg}$ of enzyme (free form); $37^{\circ} \mathrm{C}$ and $200 \mathrm{rpm}$.

\subsection{Repeated Use of LentiKats ${ }^{\circledR}$-Immobilized AMDase CEE}

The activity of immobilized AMDase was tested in 20 consecutive biocatalytic reactions (Figure 5). Each reaction took $1.5 \mathrm{~h}$, after which the particles were washed with Tris- $\mathrm{HCl}$ buffer $(100 \mathrm{mM}, \mathrm{pH} 8.5$, approx. $15 \mathrm{~mL}$ ) and used for the next reaction. The activity of immobilized AMDase CEE decreased rapidly after each biotransfomation reaction, with $90.1 \%$ loss of the initial activity (in the first reaction) after the 20th cycle. 


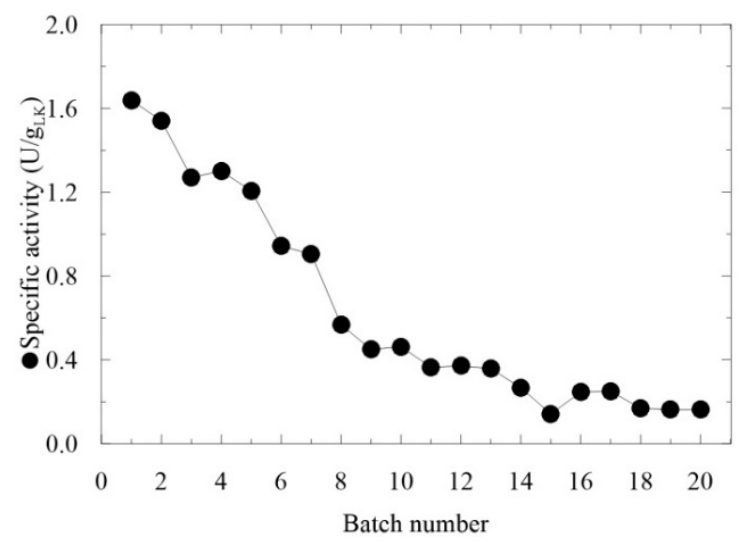

Figure 5. Repeated biocatalytic reactions with immobilized AMDase crude enzyme extract in LentiKats ${ }^{\circledR}$. Reaction conditions: $5 \mathrm{~mL}$ TrisHCl buffer $(100 \mathrm{mM}, \mathrm{pH}=8.5), \alpha$-phenylmalonic acid $1.8 \mathrm{~g} / \mathrm{L}, 0.5 \mathrm{~g}$ of LentiKats ${ }^{\circledR} ; 37^{\circ} \mathrm{C}$ and $200 \mathrm{rpm}$.

A possible explanation for this loss could be the fact that AMDase is a very small monomeric enzyme of $26 \mathrm{kDa}$. The size of the enzyme prevents it being entrapped in the pores of the LentiKats ${ }^{\circledR}$ particles created by PEG. Due to this problem, the enzyme is probably washed out after each repeated conversion (Figure 4). Therefore, various modifications of the LentiKats ${ }^{\circledR}$ preparation using different concentrations of PEG were tested to diminish the pores, but with no significant improvement in enzyme stability (See Supplementary Material 1; Figures S1,S2). Also the combination of cross-linked enzyme aggregate (CLEA) immobilization and subsequent entrapment of AMDase CLEA in LentiKats ${ }^{\circledR}$ was tested, as reported in Wilson et al. [33] and in Torello et al. [24]. However, no positive results in terms of enzyme stabilization or possibility of repeated use were obtained (See Supplementary Material 1; Figure S3).

\subsection{Immobilization of AMDase on MMP and MMP-LentiKats ${ }^{\circledR}$}

To improve the stability of the immobilized enzyme, a novel approach of combined immobilization was tested. First, AMDase CEE was immobilized on magnetic cellulose microparticles. Before immobilization, the particles were oxidized using sodium periodate to create dialdehyde cellulose [34] to which the enzyme was covalently bonded through amino groups. The concentration of protein was tested before $(11.47 \mathrm{mg} / \mathrm{mL})$ and after $(0.66 \mathrm{mg} / \mathrm{mL})$ the incubation of the activated magnetic microparticles (MMP) with the CEE, showing that only 5.8\% of the total protein was not bonded on the MMP. AMDase immobilized on MMP was used for three consecutive reactions (Figure 6). Even after the third conversion, the enzyme was still active and able to convert $100 \%$ of the substrate in $20 \mathrm{~min}$. The activity recovery was $3.24 \%$, and the specific activity dropped from $66.03 \mathrm{U} / \mathrm{mg}$ (free enzyme) to $2.14 \mathrm{U} / \mathrm{mg}$ (covalently bonded enzyme on MMP). It has been reported that immobilization using covalent binding can cause low recovery of the enzyme activity. Probable reasons for this could be the destruction of the enzyme's active conformation during the immobilization reaction, the multipoint attachment to the support, steric hindrance of the enzyme or the strong strength of the covalent binding [35]. 


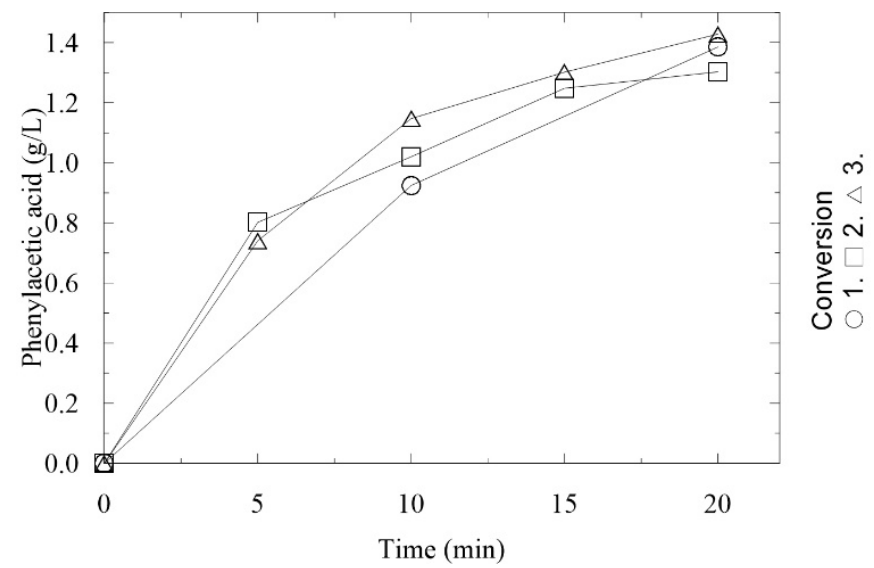

Figure 6. Three consecutive biocatalytic reactions with AMDase covalently bonded on magnetic microparticles. Reaction conditions: $5 \mathrm{~mL}$ TrisHCl buffer $(100 \mathrm{mM}, \mathrm{pH}=8.5), \alpha$-phenylmalonic acid $1.8 \mathrm{~g} / \mathrm{L}, 10 \mathrm{mg}$ of $\mathrm{MMP} ; 37^{\circ} \mathrm{C}$ and $200 \mathrm{rpm}$.

The washing and manipulation of the microparticles is difficult due to their size. For this reason a new immobilization strategy was tested. To further improve the manipulation of the particles, the AMDase CEE immobilized on MMP was then entrapped in PVA gel. Thanks to the size of the LentiKats ${ }^{\circledR}$ particles, the manipulation and washing after each reaction was significantly eased. The specific activity of the double-immobilized AMDase was $0.45 \mathrm{U} / \mathrm{mg}$. The immobilization yield of immobilized AMDase on MMP-LentiKats ${ }^{\circledR}$ was $21 \%$ (comparing to the activity of AMDase immobilized only on MMP). To verify the stability of the immobilized enzyme, eight biocatalytic reactions were performed in succession (Figure 7), without any significant loss of the activity. This demonstrates that immobilization significantly stabilized the enzyme compared to free CEE (described in Section 3.1). This proposed immobilization strategy also showed an improvement in repetitive use compared to the strategies described so far [21,22]. Double-immobilized enzyme also retained $64 \%$ of its activity after three months of storage at $4{ }^{\circ} \mathrm{C}$ (compared to $0.04 \%$ retained activity for the free enzyme after three weeks storage at the same conditions as described in Section 2.1). This also demonstrates the significant enzyme stabilization achieved by this immobilization method.

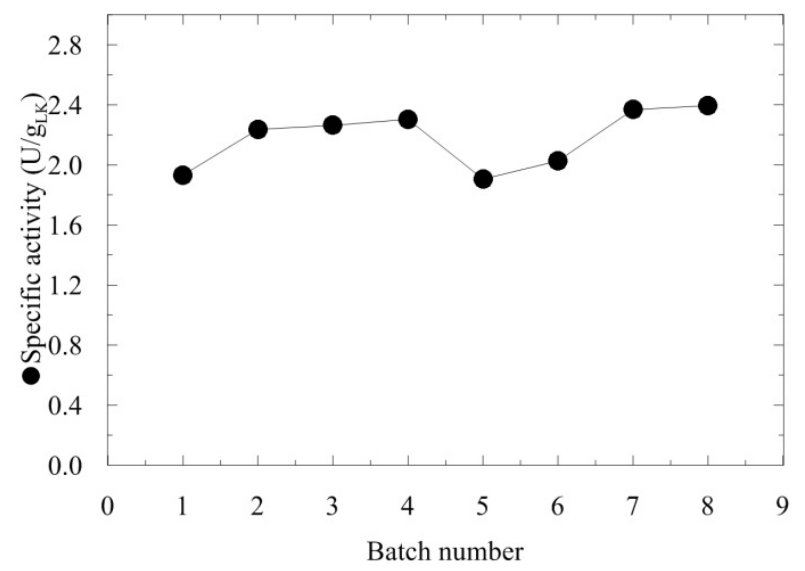

Figure 7. Repeated biocatalytic reactions with AMDase crude enzyme extract immobilized in MMP-LentiKats ${ }^{\circledR}$. Reaction conditions: $5 \mathrm{~mL}$ TrisHCl buffer $(100 \mathrm{mM}, \mathrm{pH}=8.5), \alpha$-phenylmalonic acid $1.8 \mathrm{~g} / \mathrm{L}, 0.5 \mathrm{~g}$ of MMP-LentiKats ${ }^{\circledR} ; 37^{\circ} \mathrm{C}$ and $200 \mathrm{rpm}$.

The kinetic parameters of double-immobilized AMDase (Table 1) were worse than those of AMDase only immobilized in LentiKats ${ }^{\circledR}$. That means that the covalent bonds and PVA entrapment are somehow slowing the enzyme activity and the ability to bind the substrate. However, these results do not affect the repetitive use or the stability of the enzyme as a double-immobilized catalyst. 


\section{Materials and Methods}

\subsection{Microorganism and Media}

Escherichia coli BL21 (DE3) + pET28b carrying the amd gene was cultivated in Lysogeny broth (LB) media: $5 \%(w / v)$ yeast extract, $10 \%(w / v)$ tryptone, $10 \%(w / v) \mathrm{NaCl}$. For the solid media $2 \%(w / v)$ agar was added. After autoclaving, $20 \mu \mathrm{g} / \mathrm{mL}$ of filter sterilized kanamycin (Sigma Aldrich, St. Louis, MO, USA) was added to all LB media.

\subsection{Cultivation, Induction and Crude Enzyme Preparation}

The inoculum was prepared overnight, inoculating $3 \mathrm{~mL}$ of LB media with a single colony and cultivated at $37^{\circ} \mathrm{C}$ and $200 \mathrm{rpm}$ for approximately $12 \mathrm{~h}$. $1 \%$ inoculum was transported to $200 \mathrm{~mL}$ of LB media in a $500 \mathrm{~mL}$ cultivation flask and cultivated at $37^{\circ} \mathrm{C}$ and $200 \mathrm{rpm}$ until the optical density at $600 \mathrm{~nm}\left(\mathrm{OD}_{600}\right)$ reached $0.5-0.6$. Then, $1 \mathrm{mM}$ of isopropyl $\beta-\mathrm{D}-1$-thiogalactopyranoside (IPTG) was added and the induction was performed for $20 \mathrm{~h}$ at $30^{\circ} \mathrm{C}$ and $200 \mathrm{rpm}$. The biomass was later centrifuged in $50 \mathrm{~mL}$ Falcon tubes at $4^{\circ} \mathrm{C}, 7190 \mathrm{~g}$ for $5 \mathrm{~min}$. The pellet was resuspended in $40 \mathrm{~mL}$ of Tris(hydroxymethyl)aminomethane hydrochloride buffer (Tris $\mathrm{HCl}, 100 \mathrm{mM}, \mathrm{pH}=8.5$ ). The cells were disrupted by continual cell disruptor (Constant cell disruption systems, Constant Systems LTD, Daventry, UK) in two cycles at $4{ }^{\circ} \mathrm{C}$ and 20000 PSI (Pounds per square inch; 20000 PSI= 1378,95 bar) and $50 \mu \mathrm{L}$ of protease inhibitor (Complete EDTA-free, Roche Diagnostics, Penzberg, Germany) was added. The CEE was ultracentrifuged (Avanti ${ }^{\circledR}$ centrifuge 1-30I, Beckman Coulter, Indianapolis, IN, USA) at $10^{\circ} \mathrm{C}$ and 50,000 $\mathrm{g}$ for $30 \mathrm{~min}$. The supernatant was used for activity assay and immobilization.

\subsection{Immobilization in LentiKats ${ }^{\circledR}$}

The prepared CEE was immobilized by entrapment in PVA gel using the LentiKats ${ }^{\circledR}$ system (www.lentikats.eu). $10 \mathrm{~g}$ of PVA and $6 \mathrm{~g}$ of polyethylene glycol (PEG, $1000 \mathrm{~g} / \mathrm{mol}$ ) were mixed together in $79 \mathrm{~mL}$ of distilled water. The mixture was heated to $94{ }^{\circ} \mathrm{C}$ for approx. $30 \mathrm{~min}$ at constant mixing, after which it was cooled to $40{ }^{\circ} \mathrm{C}$ and $5 \mathrm{~mL}(6.25 \mathrm{mg})$ of prepared CEE was added. The gel drops were printed on plastic carriers using laboratory equipment for immobilization (LentiPrinter ${ }^{\circledR}$ ). The immobilized enzyme particles were dried at $40{ }^{\circ} \mathrm{C}$ for approx. $45 \mathrm{~min}$ and then hardened in $0.1 \mathrm{M}$ $\mathrm{Na}_{2} \mathrm{SO}_{4}$ solution for an additional $45 \mathrm{~min}$. The immobilized enzyme was used for biocatalytic reactions or stored in Tris $\mathrm{HCl}(100 \mathrm{mM}, \mathrm{pH}=8.5)$ buffer at $4{ }^{\circ} \mathrm{C}$.

\subsection{Double-Immobilization on Microparticles and Entrapment in LentiKats ${ }^{\circledR}$}

The CEE was immobilized on magnetic PERLOZA MG 100 microparticles (MMP, PERLOZA s.r.o., Lovosice, Czech Republic) via covalent binding. These magnetic particles (diameter 80-100 $\mu \mathrm{m}$ ) consist of $85 \%$ cellulose beads (approx. 30\% of which is magnetite) and $15 \%$ demineralized water. The MMP (100 mg) were incubated with $2 \mathrm{~mL}$ of $0.05 \mathrm{M} \mathrm{NaIO}_{4}$ for $21 \mathrm{~h}$ at $4{ }^{\circ} \mathrm{C}$. Then washed 5 times with potassium phosphate buffer $(0.1 \mathrm{M}, \mathrm{pH} 8)$. CEE $(800 \mu \mathrm{L}, 14 \mathrm{mg} / \mathrm{mL})$ and potassium phosphate buffer $(800 \mu \mathrm{L}, 0.2 \mathrm{M}, \mathrm{pH} 8)$ was added to the washed MMP. After $20 \mathrm{~h}$ of incubation at $4{ }^{\circ} \mathrm{C}$ and moderate shaking, the MMP were washed 10 times with $10 \mathrm{~mL}$ of Tris-HCl buffer $(0.1 \mathrm{M}, \mathrm{pH} 8) .50 \mu \mathrm{L}$ samples were taken before and after incubation with MMP for immobilized capacity calculations (how much enzyme bound to the MMP) using protein analysis. MMP with AMDase (90 mg) were mixed with 2.9 mL PVA gel, as described in Section 3.3.

\subsection{Biocatalytic Reactions with AMDase}

CEE of AMDase in the free and immobilized form were used for decarboxylation of $\alpha$-phenylmalonic acid (Sigma Aldrich, St. Louis, MO, USA). The reaction mixture with the free enzyme contained $10 \mu \mathrm{L}(0.013 \mathrm{mg})$ of the enzyme, $1.8 \mathrm{~g} / \mathrm{L}$ of the substrate and $4.99 \mathrm{~mL}$ of Tris- $\mathrm{HCl}$ buffer (100 mM, pH 8.5). The reaction mixture with AMDase immobilized in LentiKats ${ }^{\circledR}$ contained $^{\circ}$ 
0.5/1 $\mathrm{g}$ of LentiKats ${ }^{\circledR}$ particles, $1.8 \mathrm{~g} / \mathrm{L}$ of the substrate and $5 \mathrm{~mL}$ of Tris- $\mathrm{HCl}$ buffer (100 mM, pH 8.5). The reaction mixture with AMDase immobilized on MMP contained $10 \mathrm{mg}$ of MMP particles, $1.8 \mathrm{~g} / \mathrm{L}$ of the substrate and $5 \mathrm{~mL}$ of Tris- $\mathrm{HCl}$ buffer $(100 \mathrm{mM}, \mathrm{pH}$ 8.5). The reaction mixture with AMDase immobilized on MMP entrapped in LentiKats ${ }^{\circledR}$ (MMP-LentiKats ${ }^{\circledR}$ ) contained $0.5 \mathrm{~g}$ of MMP-LentiKats $^{\circledR}$ particles, $1.8 \mathrm{~g} / \mathrm{L}$ of the substrate and $5 \mathrm{~mL}$ of Tris- $\mathrm{HCl}$ buffer $(100 \mathrm{mM}, \mathrm{pH} 8.5)$. The reactions for kinetic measurements were performed using $0.45 ; 0.9 ; 1.8 ; 2.7 ; 3.6 ; 5.4$ and $6.3 \mathrm{~g} / \mathrm{L}$ of the substrate. After each repeated biocatalytic reaction with immobilized enzyme the particles were washed with Tris- $\mathrm{HCl}$ buffer $(100 \mathrm{mM}, \mathrm{pH} 8.5$, approx. $15 \mathrm{~mL})$ before using them for another reaction.

The reactions were performed in a $50 \mathrm{~mL}$ Falcon ${ }^{\mathrm{TM}}$ conical centrifuge tube at $30^{\circ} \mathrm{C}$ and at $200 \mathrm{rpm}$ (Incubator shaker series I26, New Brunswick Scientific, Eppendorf, Berzdorf, Germany). One unit (U) of enzyme activity was defined as the amount of enzyme able to catalyse the formation of $1 \mu \mathrm{mol}$ of $\alpha$-phenylacetic acid in $1 \mathrm{~min}$ at $30^{\circ} \mathrm{C}$ and $\mathrm{pH} 8.5$.

All experiments were performed in 2 parallels and the errors were under $5 \%$.

\subsection{Activity Calculations}

The initial specific activity of free and immobilized enzyme was calculated as in Zajkoska et al., from the initial linear increase of $\alpha$-phenylacetic acid [36]. The activity of immobilized AMDase in MMP-LentiKats ${ }^{\circledR}$ was related to gram of LentiKats ${ }^{\circledR}$ used for the reaction. Detailed activity calculations are described in Supplementary Material 1.

\subsection{Analytical Methods}

The biomass concentration was measured spectrophotometrically (BioSpectrophotometer, Eppendorf, Hamburg, Germany) at $600 \mathrm{~nm}$ and the protein concentration was measured using the Bradford protein assay [37].

Processing of samples taken during biocatalytic reactions: $200 \mu \mathrm{L}$ of the sample was mixed with $100 \mu \mathrm{L}$ of $2 \mathrm{M} \mathrm{HCl}$ and centrifuged for $1 \mathrm{~min}$ at $13300 \mathrm{~g}$; the supernatant was used for HPLC analysis. The concentrations of $\alpha$-phenylmalonic and $\alpha$-phenylacetic acid were measured by HPLC with Agilent Technologies 1220 Infinity LC apparatus. The column was a Supelco Waters Spherisorb S5ODS2, $25 \mathrm{~cm} \times 4.6 \mathrm{~mm}(5 \mu \mathrm{m})$ (guarded by column with same filling $-3.2 \mathrm{~cm} \times 4.6 \mathrm{~mm}$ ); in the mobile phase, the flow rate was $0.8 \mathrm{~mL} / \mathrm{min}$ with acetonitrile, distilled water and trifluoroacetic acid (60/40/0.05), with UV detection at $245 \mathrm{~nm}$. The retention times were $3.2 \mathrm{~min}$ for $\alpha$-phenylmalonic acid and $3.9 \mathrm{~min}$ for $\alpha$-phenylacetic acid.

\section{Conclusions}

The work presented here demonstrates a novel approach to the immobilization of small enzymes and proteins. AMDase, which is a monomeric enzyme of only $26 \mathrm{kDa}$, was successfully covalently bonded to magnetic microparticles and entrapped in PVA gel. Covalent binding attached the enzyme to the magnetic microparticles and thus the enzyme did not leak from the LentiKats ${ }^{\circledR}$ particles, and the PVA gel protected the enzyme from unfavorable reaction conditions. Even though the kinetic parameters of double-immobilized AMDase were worse than the free AMDase or immobilized in PVA gel, this new method has stabilized the enzyme, which retained stable activity for eight consecutive conversions. In addition, the enzyme immobilized by the method described had significantly improved storage stability. Furthermore, the presence of a magnet in the particles might simplify the separation of the biocatalyst from reaction mixture by employing a magnetic field. The double-immobilization method developed has not previously been described and is suitable for various other small proteins or enzymes, significantly stabilizing them for repeated use.

Supplementary Materials: The following are available online at http:/ /www.mdpi.com/2073-4344/8/12/603/s1, Figure S1: Repeated biocatalytic reactions with immobilized AMDase crude enzyme extract in LentiKats ${ }^{\circledR}$ with modified PVA gel-3 g of PEG. Reaction conditions: $5 \mathrm{~mL}$ TrisHCl buffer (100 mM, pH = 8.5), $\alpha$-phenylmalonic acid $1.8 \mathrm{~g} / \mathrm{L}, 0.5 \mathrm{~g}$ of LentiKats ${ }^{\circledR} ; 37^{\circ} \mathrm{C}$ and $200 \mathrm{rpm}$. Figure S2: Repeated biocatalytic reactions with immobilized 
AMDase crude enzyme extract in LentiKats ${ }^{\circledR}$ with modified PVA gel-1 g of PEG. Reaction conditions: $5 \mathrm{~mL}$ TrisHCl buffer $(100 \mathrm{mM}, \mathrm{pH}=8.5), \alpha$-phenylmalonic acid $1.8 \mathrm{~g} / \mathrm{L}, 0.5 \mathrm{~g}$ of LentiKats ${ }^{\circledR} ; 37{ }^{\circ} \mathrm{C}$ and $200 \mathrm{rpm}$. Figure S3: Repeated biocatalytic reactions with double-immobilized AMDase crude enzyme extract in CLEA and LentiKats ${ }^{\circledR}$. Reaction conditions: $5 \mathrm{~mL}$ TrisHCl buffer $(100 \mathrm{mM}, \mathrm{pH}=8.5), \alpha$-phenylmalonic acid $1.8 \mathrm{~g} / \mathrm{L}, 0.5 \mathrm{~g}$ of LentiKats ${ }^{\circledR} ; 37^{\circ} \mathrm{C}$ and $200 \mathrm{rpm}$.

Author Contributions: K.M., J.H. and M.H. performed the experiments; M.R. designed the experimental setup; R.K. provided plasmid carrying AMD gene; R.S. and L.Z. provided microparticles for immobilization and operational manual; K.M. and M.R. analysed the data and wrote the manuscript; M.R. and M.R. contributed funding of the research.

Funding: This research was funded by the Ministry of Education, Science, Research and Sport of the Slovak Republic within the Research and Development Operational Programme for the project 'University Science Park of STU Bratislava', ITMS 26240220084.

Acknowledgments: This article was supported by the Ministry of Education, Science, Research and Sport of the Slovak Republic within the Research and Development Operational Programme for the project 'University Science Park of STU Bratislava', ITMS 26240220084.

Conflicts of Interest: The authors declare no conflict of interest.

\section{References}

1. Miyamoto, K.; Kourist, R. Arylmalonate decarboxylase- A highly selective bacterial biocatalyst with unknown function. Appl. Microbiol. Biotechnol. 2016, 100, 8621-8631. [CrossRef] [PubMed]

2. Miyamoto, K.; Ohta, H. Purification and properties of a novel arylmalonate decarboxylase from Alcaligenes bronchisepticus KU 1201. Eur. J. Biochem. 1992, 210, 475-481. [CrossRef] [PubMed]

3. Miyamoto, K.; Yatake, Y.; Tamura, K.; Terao, Y.; Ohta, H. Purification and Characterization of Arylmalonate Decarboxylase from Achromobacter sp. KU1311. J. Biosci. Bioeng. 2007, 104, 263-267. [CrossRef] [PubMed]

4. Lee, B.-S.; Yoon, Ch.W.; Osipov, A.; Moghavem, N.; Nwachokor, D.; Amatya, R.; Na, E.; Pantoja, J.L.; Pham, M.D.; Black, K.L.; Yu, J.S. Nanoprodrugs of NSAIDs: Preparation and characterization of flufenamic acid nanoprodrugs. J. Drug. Deliv. 2011, 2011, 1-13. [CrossRef] [PubMed]

5. Gaßmeyer, S.K.; Wetzig, J.; Mügge, C.; Assmann, M.; Enoki, J.; Hilterhaus, L.; Zuhse, R.; Miyamoto, K.; Liese, A.; Kourist, R. Arylmalonate decarboxylase catalyzed asymmetric synthesis of both enantiomers of optically pure flurbiprofen. Chem. Cat. Chem. 2016, 8, 916-921. [CrossRef]

6. Terao, Y.; Ijima, Y.; Miyamoto, K.; Ohta, H. Inversion of enantioselectivity of arylmalonate decarboxylase via site-directed mutation based on the proposed reaction mechanism. J. Mol. Catal. B-Enzym. 2007, 45, 15-20. [CrossRef]

7. Terao, Y.; Miyamoto, K.; Ohta, H. Improvement of the activity of arylmalonate decarboxylase by random mutagenesis. Appl. Microbiol. Biotechnol. 2006, 73, 647-653. [CrossRef]

8. Kourist, R.; Miyauchi, Y.; Uemura, D.; Miyamoto, K. Engineering the promiscuous racemase activity of an arylmalonate decarboxylase. Chem. Eur. J. 2011, 17, 557-563. [CrossRef]

9. Matoishi, K.; Ueda, M.; Miyamoto, K.; Ohta, H. Mechanism of asymmetric decarboxylation of $\alpha$-aryl- $\alpha$-methylmalonate catalyzed by arylmalonate decarboxylase originated from Alcaligenes bronchisepticus. J. Mol. Catal. B-Enzym. 2004, 27, 161-168. [CrossRef]

10. Bornscheuer, U.T. Immobilizing enzymes: How to create more suitable biocatalysts. Angew. Chem. Int. Ed. 2003, 42, 3336-3337. [CrossRef]

11. Brady, D.; Jordaan, J. Advances in enzyme immobilization. Biotechnol. Lett. 2009, 31, 1639-1650. [CrossRef] [PubMed]

12. Bommarius, A.S.; Pave, M.F. Stabilizing biocatalysts. Chem. Soc. Rev. 2013, 42, 6534-6565. [CrossRef] [PubMed]

13. Mohamad, N.R.; Marzuki, N.H.C.; Buang, N.A.; Huyop, F.; Wahab, R.A.; Mohamad. An overview of technologies for immobilization of enzymes and surface analysis techniques for immobilized enzymes. Biotechnol. Biotechnol. Equip. 2015, 29, 205-220. [CrossRef] [PubMed]

14. Krasňan, V.; Stloukal, R.; Rosenberg, M.; Rebroš, M. Immobilization of cells and enzymes to LentiKats ${ }^{\circledR}$. Appl. Microbiol. Biotechnol. 2016, 100, 2535-2553. [CrossRef] [PubMed]

15. Jesionowski, T.; Zdarta, J.; Krajewska, B. Enzyme immobilization by adsorption: a review. Adsorption 2014, 20, 801-821. [CrossRef] 
16. Zdarta, J.; Meyer, A.S.; Jesionowski, T.; Pinelo, M. A General Overview of Support Materials for Enzyme Immobilization: Characteristics, Properties, Practical Utility. Catalysts 2018, 8, 92. [CrossRef]

17. Shinkai, M. Functional magnetic particles for medical application. J. Biosci. Bioeng. 2002, 94, 606-613. [CrossRef]

18. Ngomsik, A.-F.; Bee, A.; Draye, M.; Cote, G.; Cabuil, V. Magnetic Nano- and Microparticles for Metal Removal and Environmental Applications: A. Review. C. R. Chim. 2005, 8, 963-970. [CrossRef]

19. Mehta, R.V.; Upadhyay, R.V.; Charles, S.W.; Ramchand, C.N. Direct binding of protein to magnetic particles. Biotechnol. Tech. 1997, 11, 493-496. [CrossRef]

20. Koneracká, M.; Kopčanský, P.; Timko, M.; Ramchand, C.N.; de Sequeira, A.; Trevan, M. Direct binding procedure of proteins and enzymes to fine magnetic particles. J. Mol. Catal. B-Enzym. 2002, 18, 13-18. [CrossRef]

21. Wong, L.S.; Okrasa, K.; Micklefield, J. Site-selective immobilisation of functional enzymes on to polystyrene nanoparticles. Org. Biomol. Chem. 2010, 8, 782-787. [CrossRef] [PubMed]

22. Aßmann, M.; Mügge, C.; Gaßmeyer, S.K.; Enoki, J.; Hilterhaus, L.; Kourist, R.; Liese, A.; Kara, S. Improvement of the process stability of arylmalonate decarboxylase by immobilization for biocatalytic profen synthesis. Front. Microbiol. 2017, 8, 448. [CrossRef]

23. Lakshmi, G.J.; Kotra, S.R.; Peravali, J.B.; Kumar, P.P.B.S.; Rao, K.R.S.S. Molecular cloning, high level expression and activity analysis of constructed human interleukin-25 using industrially important IPTG inducible Escherichia coli BL21(DE3). J. Biosci. Biotechnol. 2014, 6, 19-30. [CrossRef]

24. Torello, G.; van Midden, N.; Stloukal, R.; Hanefeld, U. Immobilized Hydroxynitrile Lyase: A Comparative Study of Recyclability. ChemCatChem 2014, 6, 1096-1102. [CrossRef]

25. Reboš, M.; Rosenberg, M.; Mlichová, Z.; Krištofíková, L'.; Paluch, M. A simple entrapment of glucoamylase into LentiKats ${ }^{\circledR}$ as an efficient catalyst for maltodextrin hydrolysis. Enzym. Microb. Tech. 2006, 39, 800-804. [CrossRef]

26. Dowd, J.E.; Riggs, D.S. A Comparison of Estimates of Michaelis-Menten Kinetic Constants from Various Linear Transformations. J. Biol. Chem. 1965, 240, 863-869.

27. Kawasaki, T.; Saito, K.; Ohta, H. The Mode of Substrate- Recognition Mechanism of Arylmalonate Decarboxylase. Chem. Lett. 1997, 26, 351-352. [CrossRef]

28. Okrasa, K.; Levy, C.; Hauer, B.; Baudendistel, N.; Leys, D.; Micklefield, J. Structure and Mechanism of an Unusual Malonate Decarboxylase and Related Racemases. Chem. Eur. J. 2008, 14, 6609-6613. [CrossRef] [PubMed]

29. Okrasa, K.; Levy, C.; Wilding, M.; Goodall, M.; Baudendistel, N.; Hauer, B.; Leys, D.; Micklefield, J. Structure-guided directed evolution of alkenyl and arylmalonate decarboxylases. Angew. Chem. Int. Ed. 2009, 48, 7691-7694. [CrossRef]

30. Rebros, M.; Rosenberg, M.; Mlichova, Z.; Kristofikova, L. Hydrolysis of sucrose by invertase entrapped in polyvinyl alcohol hydrogel capsules. Food Chem. 2007, 102, 784-787. [CrossRef]

31. Markošová, K.; Dolejš, I.; Stloukal, R.; Rios-Solis, L.; Rosenberg, M.; Micheletti, M.; Lye, G.J.; Turner, N.J.; Rebroš, M. Immobilisation and kinetics of monoamine oxidase (MAO-N-D5) enzyme in polyvinyl alcohol gels. J. Mol. Catal. B-Enzym. 2016, 129, 69-74. [CrossRef]

32. Cárdenas-Fernández, M.; López, C.; Álvaro, G.; López-Santín, J. Immobilized L-aspartate ammonia-lyase from Bacillus sp. YM55-1 as biocatalyst for highly concentrated L-aspartate synthesis. Bioprocess. Biosyst. Eng. 2012, 35, 1437-1444. [CrossRef] [PubMed]

33. Wilson, L.; Illanes, A.; Pessela, B.C.; Abian, O.; Fernández-Lafuente, R.; Guisán, J.M. Encapsulation of crosslinked penicillin $\mathrm{G}$ acylase aggregates in Lentikats: Evaluation of a novel biocatalyst in organic media. Biotechnol. Bioeng. 2004, 86, 558-562. [CrossRef] [PubMed]

34. Sirvio, J.; Hyvakko, U.; Liimatainen, H.; Niinimaki, J.; Hormi, O. Periodate oxidation of cellulose at elevated temperatures using metal salts as cellulose activators. Cabrohyd. Polym. 2011, 83, 1293-1297. [CrossRef]

35. Zhang, D.H.; Yuwen, L.X.; Peng, L.J. Parameters Affecting the Performance of Immobilized Enzyme. J. Chem.-NY 2013, 2013, 1-7. [CrossRef] 
36. Zajkoska, P.; Rosenberg, M.; Heath, R.; Malone, K.J.; Stloukal, R.; Turner, N.J.; Rebroš, M. Immobilised whole-cell recombinant monoamine oxidase biocatalysis. Appl. Microbiol. Biotechnol. 2015, 99, 1229-1236. [CrossRef] [PubMed]

37. Bradford, M.M. A rapid and sensitive method for the quantification of microgram quantities of protein utilizing the principle of protein-dye binding. Anal. Biochem. 1976, 72, 248-254. [CrossRef] 